\title{
PREVALENCE OF MORTALITY AND ITS DISTRIBUTION BY SEX AND AGE GROUPS IN INDOOR COVID-19 PATIENTS IN D.I.KHAN DIVISION, PAKISTAN
}

\author{
Muhammad Aamir', (D) Waleed Ahmad', (DBashir Ahmad', (DAbdurrehman Khan', \\ iD Muhammad Fawad', (D) Muhammad Abdullah² \\ 'Department of Medicine, Gomal Medical College, D.I.Khan, ${ }^{2}$ Department of Ophthalmology, King Edward \\ Medical University, Lahore, Pakistan
}

\begin{abstract}
Background: COVID-19 has become one of the leading causes of morbidity and mortality. The objectives of this study were to determine the prevalence of mortality and its distribution by sex and age groups in indoor COVID-19 patients in D.I.Khan Division, Pakistan.

Materials \& Methods: This cross-sectional study was conducted in the Department of Medicine, Gomal Medical College, D.I.Khan, Pakistan. A sample of 438 patients with positive SARS-CoV-2 RT-PCR was selected. Sex \& agegroups were two demographic and presence of mortality was a research variable. The data type for all variables was nominal, except ordinal age groups. Prevalence \& distribution were described by count and percentage with $95 \% \mathrm{Cl}$. The hypotheses were tested by chi-square goodness of fit test.

Results: Out of 438 COVID-19 patients, mortality was 43 (9.82\%), including 34 (7.76\%) men and nine (2.06\%) women. The mortality was $0 \%$ for $0-19$ years, four $(0.92 \%)$ for $20-39$ years, $12(2.74 \%)$ for $40-59$ years and 27 $(6.16 \%) \geq 60$ years. Our mortality $9.82 \%$ was lower than expected $20.95 \%(p=<.001)$. It was higher in men than women $(p=<.001)$. It was highest in age group $\geq 60$ years, while $0 \%$ in $0-19$ years. It was similar to expected by sex $(p=.070)$ and age group $(p=<.207)$.

Conclusion: Our study showed $9.82 \%$ mortality in indoor COVID-19 patients. The mortality was lower than expected. The mortality was higher in men than women. It was highest in elderly, while zero in children and adolescents. It was similar to expected by sex and age group.

KEYWORDS: COVID-19, Pneumonia, Prevalence, Distribution, Children, Elderly, Females, Males, Pandemic, D.I.Khan, Division, Chi-square Goodness of fit Test.

Cite as: Aamir M, Ahmad W, Ahmad B, Khan A, Fawad M, Abdullah M. Prevalence of mortality and its distribution by sex and age groups in indoor COVID-19 patients in D.I.Khan Division, Pakistan. Gomal J Med Sci 2021 JulSep; 19(3):91-7. https://doi.org/10.46903/gjms/19.03.1029
\end{abstract}

\section{INTRODUCTION}

1.1 Background: Coronavirus disease 19 (COVID-19) is an infectious disease caused by a novel coronavirus, which has been named by International Committee on Taxonomy of Viruses (ICTV) as severe acute respiratory syndrome coronavirus-2 (SARS-CoV-2). ${ }^{1}$

\section{Corresponding Author:}

Dr. Muhammad Aamir

Department of Medicine

Gomal Medical College

D.I.Khan, Pakistan

E-mail: aamirgandapur998@gmail.com

Date Submitted: 11-04-2021

Date Revised: 20-06-2021

Date Accepted: 26-06-2021
Corona viruses belong to subfamily Coronaviranae in the Coronaviridae family, which belongs to Nidovirales order. ${ }^{2}$ Corona virus is single stranded RNA virus \& the subfamily Coronaviranae is genotypically divided into four genera: alpha, beta, gamma \& delta Coronaviruses. ${ }^{3}$ The first case of COVID-19 was reported in December 2019 in Wuhan, China. The World Health Organization (WHO) announced COVID-19 as a global pandemic on March 11, 2020. The COVID-19 first patient in Pakistan was reported on February 26, 2020 in Karachi. $^{4}$

Patients having COVID-19 may present with symptoms of fever, cough, myalgia \& on investigations have normal or decreased leukocytes count \& radiographic evidence of pneumonia. ${ }^{5}$ In the past 2 decades, corona virus has caused three epidemic 
outbreaks, namely severe acute respiratory syndrome (SARS), Middle East respiratory syndrome (MERS) \& COVID-19. ${ }^{6}$ In SARS-CoV-2, the severity of disease ranges from common cold and pneumonia to severe acute respiratory distress syndrome which can lead to death. ${ }^{7}$ Recent epidemiological data indicate that there may be a gender predisposition to COVID-19, with men predisposed to being most severely affected, and older men accounting for most deaths. ${ }^{8}$ Majority of deaths in COVID-19 were due to complications related to sepsis, ARDS \& multi organ failure in adults with co-morbidities, whereas children having COVID-19 had better prognosis as compared to adults. ${ }^{9}$

Undurraga, et al. ${ }^{10}$ reported 444,921 cases of COVID-19 from Chile, Latin America, from March 3, 2020 to August 31, 2020, studied by Ministry of Health Surveillance EPIVIGILA. Overall mortality was 15,756 $(3.54 \%)(15,756 * 100 / 444,921=3.54)$. This mortality included $9,035(2.03 \%)(9,035 * 100 / 444,921=2.03)$ men and $6,721(1.51 \%)(6,721 * 100 / 444,921=1.51)$ women. Mortality by various age groups was as following; $33(0.01 \%)\left(33^{*} 100 / 444,921=0.01\right)$ in $0-9$ years, 20 $(0.0044 \%)(20 * 100 / 444,921=0.0044)$ in $10-19$ years, $97(0.02 \%)(97 * 100 / 444921=0.22)$ in $20-29$ years, 249 $(0.06 \%)(249 * 100 / 444,921=0.06)$ in $30-39$ years, 556 $(0.12 \%)(556 * 100 / 444,921=0.12)$ in $40-49$ years, 1581 $(0.36 \%)(1581 * 100 / 444921=0.36)$ in $50-59$ years, $3205(0.72 \%)(3205 * 100 / 444,921=0.72)$ in $60-69$ years, $4395(0.98 \%)(4395 * 100 / 444921=0.98)$ in 70 79 years and $5620(1.26 \%)(5620 * 100 / 444,921=1.26)$ in $\geq 80$ years age group.

Munayco, et al. ${ }^{11}$ reported a study from Peru for the period of March to May 2020, with overall mortality by COVID-19 as 7,660 (5.92\%) out of 129,148 suspected COVID-19 patients. Distribution by sex was more for men 5,508 $(4.26 \%)(5508 * 100 / 129148=4.26)$ than women $2,152(1.66 \%)(2152 * 100 / 129148=1.66)$. The distribution by age groups was $21(0.02 \%)$ $(21 * 100 / 129148=0.02)$ for $0-9$ years, $14(0.01 \%)$ $(14 * 100 / 129148=0.01)$ for $10-19$ years, $51(0.04 \%)$ $(51 * 100 / 129148=0.04)$ for $20-29$ years, $218(0.17 \%)$ $(218 * 100 / 129148=0.17)$ for $30-39$ years, $639(0.49 \%)$ $(639 * 100 / 129148=0.49)$ for $40-49$ years, 1430 $(1.11 \%)(1430 * 100 / 129148=1.11)$ for $50-59$ years, $2264(1.75 \%)(2264 * 100 / 129148=1.75)$ for $60-69$ years, $1837(1.42 \%)(1837 * 100 / 129148=1.42)$ in 70 79 years and $1186(0.92 \%)(1186 * 100 / 129148=0.92)$ in $\geq 80$ years age group.

Wu C, et al. ${ }^{12}$ from Wuhan, China from December 25, 2019 to February 13, 2020 reported 201 COVID-19 patients. Overall mortality was $44(21.89 \%)$ $(44 * 100 / 201=21.89)$. This mortality included 29 $(14.43 \%)(29 * 100 / 201=14.43)$ men and $15(7.46 \%)$ $(15 * 100 / 210=7.46)$ women.

Sarfaraz, et al. ${ }^{13}$ reported 170 serious indoor COVID-19 positive cases from Karachi, Pakistan from March 19 to June 7, 2020. Overall mortality was $67(39.41 \%)\left(67^{*} 100 / 170=39.41\right)$. This mortality included $52(30.59 \%)(52 * 100 / 3851=30.59)$ men and $15(8.82 \%)(15 * 100 / 175=8.82)$ women. Age group wise mortality was $24(14.12 \%)(24 * 100 / 170=14.12)$ in $\leq 60$ years and $43(25.29 \%)(43 * 100 / 170=25.29)$ in $>60$ years.

1.2 Research Objectives (ROs): The objectives of this study were;

RO 1: To determine the prevalence of mortality of COVID-19 in D.I.Khan Division.

RO 2-3: To determine the distribution of COVID-19 mortality by sex \& age groups in D.I.Khan Division.

\subsection{Research (Null) Hypotheses (RHs)}

$\mathbf{H}_{01}$ : The observed prevalence of mortality of COVID-19 is similar to its expected prevalence in D.I.Khan Division.

$\mathbf{H}_{02}$ : The observed distribution of mortality of COVID-19 by sex is similar to its expected distribution in D.I.Khan Division, Pakistan.

$\mathbf{H}_{03}$ : The observed distribution of mortality of COVID-19 by sex is similar to its expected distribution in D.I.Khan Division.

1.4 Significance: Having local data available on prevalence \& distribution of mortality in COVID-19 cases in D.I.Khan Division, we can know about the sex \& age groups having severe disease and highest mortality. This data can help public health officials to pursue potent actions to decrease mortality, particularly in age groups with highest risk of mortality.

\section{MATERIALS AND METHODS}

2.1 Study Design, Setting \& Duration: This cross-sectional study was conducted in the Department of Medicine, Gomal Medical College, D.I.Khan, Pakistan from March 14, 2020 to April 6, 2021. The data was collected from IPMS system of COVID-19 ICU, HDU \& Isolation Unit of MMM Teaching Hospital, D.I.Khan. Approval for the project was granted by the Institutional Ethical Committee.

2.2 Population \& Sampling: As per 2017 census, the population of D.I.Khan Division was 2,803,147. For 2020, it was assumed to be 3 million; our population at risk. Using Raosoft ${ }_{\circledast}$ online sample size calculator, ${ }^{14}$ sample size was calculated to be 438 , with $95 \% \mathrm{CL}, 0.932 \%$ margin of error, assumed prevalence of COVID-19 as $1 \%$ and population size of 3 million. The technique was consecutive. All the indoor (ICU, HDU \& Isolation Unit) COVID-19 patients were eligible for inclusion in the study. A total of 2,825 suspected COVID-19 patients were admitted in ICU, HDU and Isolation Unit for the period of the study; out of which 438 cases were confirmed by SARS-CoV-2 RT-PCR.

2.3 Conduct of Procedure: The first step was sample collection which was conducted by nasopharyngeal swab. The swab was put in a vial containing 
buffer solution which preserves the virus till the time the sample is processed. The second step was RNA extraction process, which converts RNA to DNA using Mag-Bind RNA Extraction Kit (Maccura \& Big Fish companies). The third step was Master Mix process conducted in OOVSIGN machine. The final step is Amplification by PCR machine (Singuway Company) with SARS-CoV-2 specific primers. The presence of viral RNA indicates active SARS-CoV-2 infection. All these patients were investigated and managed as per standard clinical protocols.

2.4: Data Collection Plan: Sex (men/ women) \& age-groups (0-19 years i.e. children \& adolescents, 20-39 years i.e. early adult hood, $40-59$ years i.e. late adult hood and $\geq 60$ years i.e. elderly) were our two demographic variables and the presence of mortality was our single research variable. The data type for all these variables was nominal except age groups which was ordinal. A structured Performa was used as data collection tool to collect primary data from patients. Secondary data was collected through literature research.

\subsection{Data Analysis Plan}

2.5.1 Descriptive Statistics and Estimation of $\mathrm{Pa}$ rameters: All three variables being categorical were described by count \& percentage. The estimated population parameters were given as confidence interval $(\mathrm{Cl})$ for proportion at $95 \%$ confidence level using Wilson score interval for binominal distribution. This calculation was done by using Statistics Kingdom calculator. ${ }^{15}$

2.5.2 Hypotheses Testing: Three hypotheses were substantiated by chi-square goodness of fit test, ${ }^{16,17}$ using online statistical calculators; Statulator ${ }^{18}$ for $\mathrm{H}_{01} \& \mathrm{H}_{02}$ and Statistics Kingdom Calculator ${ }^{15}$ for $\mathrm{H}_{03}$. Observed \& expected counts, chi-square values are given with significance ( $p$-value).

\section{RESULTS}

3.1.1 Prevalence of mortality: The overall mortality was $9.82 \%$ (95\%CL 07.37-12.96) i.e. 43 among 438 COVID-19 patients. (Table 3.1.1)

3.1.2: Distribution of mortality by sex \& age groups: Prevalence of mortality was higher in men $7.76 \%(95 \%$ CL $5.60-10.65)$ than women $2.06 \%$ (95\%CL 1.08-3.85). It was highest in age group $\geq 60$ years $6.16 \%$ (95\%CL 4.27-8.82), followed by $40-59$ years $2.74 \%$ (95\%CL 1.57-4.72). (Table 3.1.2)

\subsection{Hypotheses Testing}

3.2.1 Observed vs. expected prevalence of mortality $\left(\mathrm{H}_{01}\right)$ : Chi-square goodness-of-fit test verifies the difference between the observed counts from our sample $(n=438)$ in column 2 (C2) against expected counts (C3) from a study by Wu C, et al. ${ }^{12}$ from Wuhan, China $(n=210)$. With difference in sample sizes, the expected counts are adjusted to

Table 3.1.1: Prevalence of mortality in indoor COVID-19 patients in D.I.Khan Division

\begin{tabular}{|l|l|c|c|c|c|}
\hline \multirow{2}{*}{ Variable } & \multirow{2}{*}{ Attributes } & \multicolumn{2}{|c|}{ Sample Statistics } & \multicolumn{2}{c|}{$95 \% \mathrm{Cl}$ for proportion } \\
\cline { 3 - 6 } & & Count & Percentage & Lower & Upper \\
\hline \multirow{2}{*}{ Presence of mortality } & Yes & 43 & 09.82 & 07.37 & 12.96 \\
\cline { 2 - 6 } & No & 395 & 90.18 & 87.03 & 92.62 \\
\hline \multicolumn{2}{|c|}{ Total } & 438 & $100 \%$ & \multicolumn{2}{c|}{ Population Parameters } \\
\hline
\end{tabular}

Table 3.1.2: Distribution of mortality by sex $\&$ age groups in indoor COVID-19 patients in D.I.Khan Division, Pakistan $(n=438)$

\begin{tabular}{|c|c|c|c|c|c|c|}
\hline \multirow{2}{*}{ Variables } & \multirow{2}{*}{ Attributes } & \multirow{2}{*}{ Sample Size } & \multicolumn{2}{|c|}{ Sample Statistics } & \multicolumn{2}{|c|}{$95 \% \mathrm{Cl}$ for proportion } \\
\hline & & & Count & Percentage & Lower & Upper \\
\hline \multirow{2}{*}{ Sex } & Men & 318 & 34 & $34 * 100 / 438=7.76$ & 05.60 & 10.65 \\
\hline & Women & 120 & 09 & $09 * 100 / 438=2.06$ & 01.08 & 03.85 \\
\hline \multirow{4}{*}{$\begin{array}{l}\text { Age Groups } \\
\text { (Years) }\end{array}$} & $0-19$ & 27 & 0 & 0 & 0 & 0 \\
\hline & 20-39 & 162 & 04 & $4 * 100 / 438=0.92$ & 00.35 & 02.32 \\
\hline & $40-59$ & 157 & 12 & $12 * 100 / 438=2.74$ & 01.57 & 04.72 \\
\hline & $\geq 60$ & 92 & 27 & $27 * 100 / 438=6.16$ & 04.27 & 08.82 \\
\hline \multirow{2}{*}{ Mortality } & Yes & \multirow{2}{*}{438} & 43 & $43 * 100 / 438=9.82$ & 07.37 & 12.96 \\
\hline & No & & 395 & $395 * 100 / 438=90.18$ & 87.03 & 92.62 \\
\hline \multicolumn{3}{|c|}{ Total } & 438 & $100 \%$ & \multicolumn{2}{|c|}{ Population parameters } \\
\hline
\end{tabular}


our sample size (C4). C5, C6 \& C7 shows relevant percentages. (Table 3.2.1.1)

With $\mathrm{p}$-value $<.001, \mathrm{H}_{01}$ is rejected, confirming that the observed counts are different from the expected counts. Simply, our observed prevalence $9.82 \%$ is lower than expected prevalence $20.95 \%$ from a study by Wu C, et al. ${ }^{12}$ (Table 3.2.1.2)

3.2.2 Observed vs. expected distribution of COVID-19 mortality by sex $\left(\mathrm{H}_{02}\right)$ : Chi-square goodness-of-fit test testifies the difference between the observed counts from our sample $(n=43)$ in column 2 (C2) against expected counts (C3) from a study by Wu C, et al. ${ }^{12}$ from Wuhan, China $(n=210)$. With difference in sample sizes/ denominators, the expected counts are adjusted to our sample size (C4). C5, C6 \& C7 shows relevant percentages. (Table 3.2.2.1)

With p-value $.070, \mathrm{H}_{02}$ is accepted, confirming that the observed counts are statistically similar to the expected counts. Simply, our observed prevalence $7.76 \%$ for men is similar to what was expected $6.47 \%$ for men and our observed prevalence $2.06 \%$ for women is similar to what was expected $3.35 \%$ for women from a study by Wu C, et al. ${ }^{12}$ (Table 3.2.2.2)

Table 3.2.1.1: Observed, expected \& adjusted expected counts and \%ages for prevalence of mortality in indoor COVID-19 patients in D.I.Khan Division, Pakistan $(n=438)$

\begin{tabular}{|l|c|c|c|c|c|c|}
\hline $\begin{array}{l}\text { Column 1- } \\
\text { Mortality }\end{array}$ & $\begin{array}{c}\text { C2-Observed } \\
\text { counts }\end{array}$ & $\begin{array}{c}\text { C3-Expected } \\
\text { counts }\end{array}$ & $\begin{array}{c}\text { C4-Adjusted ex- } \\
\text { pected counts }\end{array}$ & $\begin{array}{c}\text { C5-Observed } \\
\% \text { ages }\end{array}$ & $\begin{array}{c}\text { C6-Expected } \\
\% \text { ages }\end{array}$ & $\begin{array}{c}\text { C7-Adjusted ex- } \\
\text { pected \% }\end{array}$ \\
\hline Yes & 43 & 44 & $\begin{array}{c}44^{*} 438 / 210 \\
=91.77\end{array}$ & $9.82 \%$ & $20.95 \%$ & $\begin{array}{c}91.77^{*} 100 / 438 \\
=20.95 \%\end{array}$ \\
\hline No & 395 & 166 & $\begin{array}{c}166^{\star} 438 / 210 \\
=346.23\end{array}$ & $90.18 \%$ & $79.05 \%$ & $\begin{array}{c}346.23 * 100 / 438 \\
=79.05 \%\end{array}$ \\
\hline Total & 438 & 210 & 438 & $100 \%$ & $100 \%$ & $100 \%$ \\
\hline
\end{tabular}

Table 3.2.1.2: Observed vs. expected prevalence of mortality in indoor COVID-19 patients in population of D.I.Khan Division, Pakistan $(n=438)$

\begin{tabular}{|c|c|c|c|c|c|c|c|c|}
\hline \multirow{2}{*}{$\begin{array}{l}\text { Presence of } \\
\text { Mortality }\end{array}$} & \multirow{2}{*}{$\begin{array}{c}\text { Observed count } \\
\text { (proportion) }\end{array}$} & \multicolumn{2}{|c|}{$95 \% \mathrm{Cl}$ for proportion } & \multirow{2}{*}{$\begin{array}{c}\text { Expected count } \\
\text { (proportion) }\end{array}$} & \multicolumn{2}{|c|}{ Chi-square test } & \multicolumn{2}{|c|}{$Z$ test } \\
\hline & & Lower & Upper & & $\sum x^{2}$ & $\mathrm{p}$-value & Z-value & $\mathrm{p}$-value \\
\hline Yes & $43(0.10)$ & 0.07 & 0.13 & $91.77(0.21)$ & \multirow{2}{*}{32.78} & \multirow{2}{*}{$<.001$} & -5.73 & $<.001$ \\
\hline No & $395(0.90)$ & 0.87 & 0.93 & $346.23(0.79)$ & & & 5.73 & $<.001$ \\
\hline Total & $438(1.00)$ & & & $438(1.00)$ & $\mathrm{H}_{01}$ rej & ected at & pha .05 & d.f. $=1$ \\
\hline
\end{tabular}

Table 3.2.2.1: Observed, expected \& adjusted expected counts and \%ages for distribution of mortality by sex in indoor COVID-19 patients in D.I.Khan Division, Pakistan $(n=438)$

\begin{tabular}{|l|l|l|l|l|l|l|}
\hline Column1- Sex & $\begin{array}{l}\text { C2-Observed } \\
\text { counts }\end{array}$ & $\begin{array}{l}\text { C3-Expect- } \\
\text { ed counts }\end{array}$ & $\begin{array}{l}\text { C4-Adjusted ex- } \\
\text { pected counts }\end{array}$ & $\begin{array}{l}\text { C5-Observed } \\
\% a g e s\end{array}$ & $\begin{array}{l}\text { C6-Expected } \\
\text { \%ages }\end{array}$ & $\begin{array}{l}\text { C7-Adjusted } \\
\text { expected \% }\end{array}$ \\
\hline Men & 34 & 29 & $\begin{array}{l}29^{\star} 43 / 44 \\
=28.34\end{array}$ & $\begin{array}{l}34^{\star} 100 / 438 \\
=7.76 \%\end{array}$ & $\begin{array}{l}29^{\star} 100 / 210 \\
=13.81 \%\end{array}$ & $\begin{array}{l}28.34^{\star} 100 / 438 \\
=6.47 \%\end{array}$ \\
\hline Women & 09 & 15 & $\begin{array}{l}15^{\star} 43 / 44 \\
=14.66\end{array}$ & $\begin{array}{l}9^{\star} 100 / 438 \\
=2.06 \%\end{array}$ & $\begin{array}{l}15^{\star} 100 / 210 \\
=7.14 \%\end{array}$ & $\begin{array}{l}14.66^{\star} 100 / 438 \\
=3.35 \%\end{array}$ \\
\hline Total & 43 & 44 & 43 & $\begin{array}{l}43^{\star} 100 / 438 \\
=9.82 \%\end{array}$ & $\begin{array}{l}44^{\star} 100 / 210 \\
=20.95 \%\end{array}$ & $\begin{array}{l}43^{\star} 100 / 438 \\
=9.82 \%\end{array}$ \\
\hline
\end{tabular}

Table 3.2.2.2: Observed vs. expected distribution of mortality by sex in indoor COVID-19 patients in D.I.Khan Division, Pakistan $(n=438)$

\begin{tabular}{|l|c|c|c|c|c|c|c|}
\hline \multirow{2}{*}{$\begin{array}{l}\text { Mortality by } \\
\text { sex }\end{array}$} & \multirow{2}{*}{$\begin{array}{c}\text { Observed count } \\
\text { (proportion) }\end{array}$} & \multicolumn{2}{|c|}{$95 \% \mathrm{Cl}$ for proportion } & \multirow{2}{*}{$\begin{array}{c}\text { Expected count } \\
\text { (proportion) }\end{array}$} & \multicolumn{3}{|c|}{ Chi-square test } \\
& & Lower & Upper & & $\Sigma x^{2}$ & d.f. & p-value \\
\hline Men & $34(0.79)$ & 0.67 & 0.91 & $28.34(0.66)$ & & & \\
\hline Women & $09(0.21)$ & 0.09 & 0.33 & $14.66(0.34)$ & & 1 & .070 \\
\hline Total & $43(1.00)$ & & & $43(1.00)$ & $\mathrm{H}_{01}$ accepted at alpha .05 \\
\hline
\end{tabular}


Table 3.2.3.1: Observed, expected \& adjusted expected counts and \%ages for distribution of mortality by age groups in indoor COVID-19 patients in D.I.Khan Division $(n=438)$

\begin{tabular}{|l|c|c|c|c|c|c|}
\hline $\begin{array}{l}\text { Column 1-Age } \\
\text { groups }\end{array}$ & $\begin{array}{l}\text { C2-Observed } \\
\text { counts }\end{array}$ & $\begin{array}{c}\text { C3-Expect- } \\
\text { ed counts }\end{array}$ & $\begin{array}{c}\text { C4-Adjusted ex- } \\
\text { pected counts }\end{array}$ & $\begin{array}{c}\text { C5-Observed } \\
\text { \%ages }\end{array}$ & $\begin{array}{c}\text { C6-Expected } \\
\text { \%ages }\end{array}$ & $\begin{array}{c}\text { C7-Adjusted ex- } \\
\text { pected \%ages }\end{array}$ \\
\hline 0-19 years & 0 & 35 & $\begin{array}{c}35^{\star} 43 / 7660 \\
=0.196\end{array}$ & $\begin{array}{c}0 * 100 / 438 \\
=0 \%\end{array}$ & $\begin{array}{c}35^{\star} 100 / 129148 \\
=0.03 \%\end{array}$ & $\begin{array}{c}0.196 * 100 / 438 \\
=0.05 \%\end{array}$ \\
\hline $20-39$ years & 04 & 269 & $\begin{array}{c}269 * 43 / 7660 \\
=1.510\end{array}$ & $\begin{array}{c}4 * 100 / 438 \\
=0.92 \%\end{array}$ & $\begin{array}{c}269 * 100 / 129148 \\
=0.21 \%\end{array}$ & $\begin{array}{c}1.510^{*} 100 / 438 \\
=0.34 \%\end{array}$ \\
\hline $40-59$ years & 12 & 2069 & $\begin{array}{c}2069 * 43 / 7660 \\
=11.615\end{array}$ & $\begin{array}{c}12^{*} 100 / 438 \\
=2.74 \%\end{array}$ & $\begin{array}{c}2069 * 100 / 129148 \\
=1.60 \%\end{array}$ & $\begin{array}{c}11.615^{*} 100 / 438 \\
=2.65 \%\end{array}$ \\
\hline$\geq 60$ years & 27 & 5287 & $\begin{array}{c}5287 * 43 / 7660 \\
=29.679\end{array}$ & $\begin{array}{c}27^{*} 100 / 438 \\
=6.16 \%\end{array}$ & $\begin{array}{c}5287^{*} 100 / 129148 \\
=4.09 \%\end{array}$ & $\begin{array}{c}29.679 * 100 / 438 \\
=6.78 \%\end{array}$ \\
\hline Total & 43 & 7660 & 43 & $9.82 \%$ & $\begin{array}{c}7660 * 100 / 129148 \\
=5.93 \%\end{array}$ & $\begin{array}{c}43 * 100 / 438 \\
=9.82 \%\end{array}$ \\
\hline
\end{tabular}

Table 3.2.3.2: Observed vs. expected distribution of mortality by age groups in indoor COVID-19 patients in D.I.Khan Division, Pakistan $(n=438)$

\begin{tabular}{|l|c|c|c|c|c|c|c|}
\hline Age Groups & Observed Counts (O) & Expected Counts(E) & O-E & $(\mathrm{O}-\mathrm{E})^{2}$ & $\mathrm{X}^{2}$ & $\Sigma \mathrm{X}^{2}$ & $\mathrm{p}$-value \\
\hline 00-19 years & 00 & 00.20 & -0.20 & 0.04 & 0.20 & & \\
\cline { 1 - 6 } 20-39 years & 04 & 01.51 & 2.49 & 6.20 & 4.11 & \multirow{2}{*}{4.56} & \multirow{2}{*}{.207} \\
\hline $40-59$ years & 12 & 11.61 & 0.39 & 0.15 & 0.01 & & \\
\hline$\geq 60$ years & 27 & 29.68 & -2.68 & 7.18 & 0.24 & & \\
\hline Total & 43 & 43 & 00 & $\mathrm{H}_{03}$ accepted at alpha .05 & d.f. $=3$ \\
\hline
\end{tabular}

3.2.3 Observed vs. expected distribution of COVID-19 mortality by age groups $\left(\mathrm{H}_{02}\right)$ : Chisquare goodness-of-fit test testifies the difference between the observed counts from our sample $(\mathrm{n}=438)$ in column 2 (C2) against expected counts (C3) from a study by Munayco, et al. ${ }^{11}$ from Peru $(n=129,148)$. With difference in sample sizes/ denominators, the expected counts are adjusted to our sample size (C4). C5, C6 \& C7 shows relevant percentages. (Table 3.2.3.1)

With p-value $0.207, \mathrm{H}_{02}$ was accepted, confirming that the observed counts are statistically similar to the expected counts. Simply, our observed prevalence in each of our four age groups is similar to what was expected for these four age groups from a study by Munayco, et al. ${ }^{11}$ from Peru $(\mathrm{n}=129,148)$. (Table 3.2.3.2)

\section{DISCUSSION}

4.1 Prevalence of mortality in indoor COVID-19 patients $\left(\mathbf{H}_{01}\right)$ : The prevalence of mortality in COVID-19 in our study was $9.82 \%(95 \% \mathrm{Cl} 7.37 \%-12.96 \%)$. Higher mortality to our study was reported by Sarfaraz, et al. ${ }^{13}$ from Karachi, Pakistan from March 19 to June 7,2020 as $39.411764 \%$ and by Wu C, et al. ${ }^{12}$ from Wuhan, China for the period from December 25, 2019 to February 13,2020 as $21.89 \%$.
Lower prevalence was reported by Undurraga, et al. ${ }^{10}$ from Chile, Latin America from March 3 to August 31, 2020 as $3.5413 \%$ and Munayco, et al. ${ }^{11}$ from Peru for the period of March to May, 2020 as 5.92\%. No Study could be retrieved from the literature which showed similar prevalence of COVID-19 mortality to our study.

4.2 Distribution of mortality in indoor COVID-19 patients by sex $\left(\mathbf{H}_{02}\right)$ : The prevalence of COVID-19 mortality in our study was more in men $7.76 \%$ $(95 \% \mathrm{Cl} 5.60-10.65)$ than women $2.06 \%(95 \% \mathrm{Cl}$ 1.08-3.85). Similar to our study was reported by Undurraga, et al. ${ }^{10}$ from Chile, Latin America with higher mortality $2.0306 \%$ in men than $1.5106 \%$ women and by Munayco, et al. ${ }^{11}$ from Peru, North America having higher mortality $4.26 \%$ in men than $1.66 \%$ women. Similarly Wu C, et al. ${ }^{12}$ from Wuhan, China reported higher mortality $14.43 \%$ in men than $7.46 \%$ women and Sarfaraz, et al. ${ }^{13}$ from Karachi, Pakistan reported higher mortality $30.59 \%$ in men than $8.82 \%$ women. No study could be retrieved from literature which showed similar or higher mortality in women than men.

4.3 Distribution of COVID-19 mortality in indoor patients by age groups $\left(\mathrm{H}_{03}\right)$ : The prevalence of COVID-19 mortality in our study was highest $6.1644 \%$ $(4.27-8.82)$ in age group $\geq 60$ years \& lowest $0 \%$ in 0-19 years age group. Similar to our study was 
reported from Peru by Munayco, et al. ${ }^{11}$ from March to May 2020 having highest $4.0937 \%$ mortality in $\geq 60$ years age group and lowest $0.0271 \%$ in $0-19$ years. Matching to our study was also reported from Chile, North America by Undurraga, et al. ${ }^{10}$ having highest mortality $0.01191 \%$ in $\geq 60$ years age group \& lowest $2.2509 \%$ in 0-19 years. None of the study from literature was having mortality higher in reciprocal order.

This study has few limitations. Firstly, some of the patients could not be followed up to their final outcome, since some patients were discharged once their symptoms were improved. Secondly few patients were also referred on their own request to higher centers for the management.

This study provides an important data on COVID-19 mortality distribution on basis of sex \& various age groups. So, timely identification of COVID-19 patients at high risk of mortality can significantly improve proper management and resource allocation within hospitals. This study helps in providing data-driven approach to the understanding of male-female mortality risk and age related mortality risk. Without these data, the public are unaware about their disease risk and public policy responses cannot be specifically targeted.

4.4 Marwat Logical Trajectory of Research Process: We have adapted this logical and chronological trajectory in this study as devised by Dr. Muhammad Marwat. ${ }^{19-22}$

\section{CONCLUSIONS \& RECOMMENDATIONS}

Our study showed $9.82 \%$ mortality in indoor COVID-19 patients. The mortality was lower than expected. The mortality was higher in men than women. It was highest in elderly, while zero in children and adolescents. It was similar to expected by sex and age group.

\section{REFERENCES}

1. World Health Organization. Coronavirus Disease 2019 (COVID-19) Situation Report- 65. Geneva: World Health Organization; 2020.

2. Mohamadian M, Chiti H, Shoghli A, Biglari S, Parsamanesh N, Esmaeilzadeh A. COVID-19: Virology, biology and novel laboratory diagnosis. The J Gene Med 2021 Feb;23(2):e3303. https:// doi.org/10.1002/jgm.3303

3. Hosseini ES, Kashani NR, Nikzad H, Azadbakht $\mathrm{J}$, Bafrani HH, Kashani HH. The novel coronavirus Disease-2019 (COVID-19): Mechanism of action, detection and recent therapeutic strategies. Virology 2020 Dec 1;551:1-9. https://doi.org/10.1016/j. virol.2020.08.011

4. Abid K, Bari YA, Younas M, Tahir Javaid S, Imran A. Progress of COVID-19 epidemic in Pakistan. Asia Pac J Public Health 2020 May;32(4):154-6. https:// doi.org/10.1177/1010539520927259
5. Wit E de, Doremalen NV, Falzarano D, Munster VJ. SARS and MERS: recent insights into emerging corona virus. Nat Rev Microbiol 2016;14: 523-534. https://doi.org/10.1038/nrmicro.2016.81

6. Zhou P, Yang XL, Wang XG, Hu B, Zhang L, Zhang $W$, et al. A pneumonia outbreak associated with a new corona virus of probable bat origin. Nature 2020;579(7798):270-3. https://doi.org/10.1038/ s41586-020-2012-7

7. Cameron MJ, Ran L, Xu L, Danesh A, Bermejo-Martin JF, Cameron CM. Interferon-mediated immunopathological events are associated with atypical innate and adaptive immune responses in patients with severe acute respiratory syndrome. J Virol 2007;81(16):8692-706. https://doi. org/10.1128/JVI.00527-07

8. Papadopoulos V, Li L, Samplaski M. Why does COVID-19 kill more elderly men than women? Is there a role for testosterone? Andrology 2021 Jan;9(1):65-72. https://doi.org/10.1111/andr.12868

9. Chan KS, Zheng JP, Mok YW, Li YM. SARS: prognosis, outcome and sequel. Respirology 2003;8 Suppl:S36-40. https://doi.org/10.1046/j.14401843.2003.00522.x

10. Undurraga EA, Chowell G, Mizumoto K. COVID-19 case fatality risk by age and gender in a high testing setting in Latin America: Chile, March-August 2020. Infect Dis Poverty 2021 Dec;10(1):1-1. https://doi.org/10.1186/s40249-020-00785-1

11. Munayco C, Chowell G, Tariq A, Undurraga EA, Mizumoto K. Risk of death by age and gender from COVID-19 in Peru, March-May, 2020. Aging 2020 Jul 31;12(14):13869-81. https://doi.org/10.18632/ aging. 103687

12. Wu C, Chen X, Cai Y, Zhou X, Xu S, Huang H, et al. Risk factors associated with acute respiratory distress syndrome and death in patients with coronavirus disease 2019 pneumonia in Wuhan, China. JAMA Int Med 2020 Jul 1;180(7):934-43. https://doi.org/10.1001/jamainternmed.2020.0994

13. Sarfaraz S, Shaikh Q, Saleem SG, Rahim A, Herekar FF, Junejo $S$, et al. Determinants of in-hospital mortality in COVID-19: a prospective cohort study from Pakistan. PLoS One 2021 May27;16(5):e0251754. https://doi.org/10.1371/ journal.pone.0251754

14. Raosoft ${ }^{\circledR}$ sample size calculator [internet]. Seattle, WA, USA: Raosoft Inc.; 2004. [accessed 2021 April 10]. Available at: http://www.raosoft.com/ samplesize.html

15. Statistics Kingdom. Proportion confidence interval calculator [internet]. Statistics Kingdom; Melbourne, Australia 2007 [accessed 2021 Apr 10]. Available at: https://www.statskingdom.com/ proportion-confidence-interval-calculator.html

16. Zar JH. Biostatistical Analysis. 5th ed. New York: Prentice-Hall, Inc.

17. Daniel WW. Biostatistics: A Foundation for Analysis in the Health Sciences. 7th ed. Singapore: John Wily; 2005. 
18. Statulator. Statistical Tests [accessed 2021 Apr 10]. Available at: https://statulator.com/stat/ chisq-gof.html

19. Ain N, Khan S, Marwat M, Khan N, Ahmad I, Ramzan $\mathrm{F}$, et al. Frequency, distribution and determinants of hypertension in adult stroke population of D.I.Khan Division, Pakistan. Gomal J Med Sci 2019 Jul-Sep; 17 (3):81-9. https://doi. org/10.46903/gjms/17.03.2076

20. Marwat M, Ahmad I, Ashiq F, AliS, ZamirS, Rehman MU, et al. Frequency, distribution and determinants of diabetes mellitus in adult acute coronary syndrome population of D.I.Khan Division, Pakistan. Gomal J Med Sci 2019 Oct-
Dec;17(4):131-43. https://doi.org/10.46903/ gjms/17.04.2106

21. Naqvi SWA, Saeed S, Rafique A, Saeed MH, Khan $\mathrm{N}$, Khan $\mathrm{A}$, et al. Prevalence and distribution of malaria by sex, age groups and species in year 2019 in suspected malarial population of district D.I.Khan, Pakistan. Gomal J Med Sci 2020 OctDec; 18(4):164-73.

22. Rashid M, Rehman $Y$, Usman $M$, Younas $M$, Bilal M, Jamil M, et al. Distribution of cutaneous leishmaniasis by sex, age groups and residence in year 2020 in cutaneous leishmaniasis population of District D.I.Khan, Pakistan. Gomal J Med Sci 2021 Jan-Mar; 19(1):28-34.

CONFLICT OF INTEREST

Authors declare no conflict of interest. GRANT SUPPORT AND FINANCIAL DISCLOSURE None declared.

\section{AUTHORS' CONTRIBUTION}

The following authors have made substantial contributions to the manuscript as under:

Conception or Design: $\quad$ MA, WA, AK

Acquisition, Analysis or Interpretation of Data: $\quad$ MA, WA, BA, AK, MF, MA

Manuscript Writing \& Approval: $\quad$ MA, WA, BA, AK, MF, MA

All the authors agree to be accountable for all aspects of the work in ensuring that questions related to the accuracy or integrity of any part of the work are appropriately investigated and resolved. 